\title{
Epidemiological characterisation of Neisseria gonorrhoeae isolates from the Far East
}

\author{
T O ODUGBEMI, * W L WHITTINGTON, * W DEWITT, * G PERKINS, * \\ S JOHNSON, * J BIDDLE, * M PIZIAK, † AND W L ALBRITTON* \\ From the *Centers for Disease Control, Atlanta, Georgia, and the +Walter Reed Army Institute of \\ Research, Washington DC, USA
}

SUMMARY One hundred strains of Neisseria gonorrhoeae (including 30 penicillinase producing (PPNG) strains) originating from Korea were characterised by plasmid analysis, auxotyping, and serogrouping. Eighty per cent of the isolates possessed the conjugative $24 \cdot 5$ megadalton (Mdal) plasmid. A novel 7.8 Mdal plasmid was present in four isolates (one PPNG and three non-PPNG strains). Seventy five per cent of all the strains tested were wild type and belonged to serogroup WII, while $20 \%$ were proline requiring and belonged to serogroup WII. Two of the remaining strains were tyrosine auxotrophs, while another strain was arginine requiring; these three strains carried the conjugative plasmid and belonged to serogroup WII.

\section{Introduction}

Since the emergence of penicillinase producing Neisseria gonorrhoeae (PPNG) in $1976,{ }^{1-3}$ the $\beta$-lactamase R-plasmids have been useful as additional epidemiological markers for tracing the possible geographical source of PPNG. The R-plasmid with a molecular weight of 3.2 megadaltons (Mdal) was associated with PPNG isolates from West Africa, while the $4 \cdot 4$ Mdal R-plasmid was associated with the Far East. ${ }^{4-6}$ The 24.5 Mdal plasmid had the ability to mobilise R-plasmids conjugally, ${ }^{7}$ and it was found more commonly in about $34 \%$ of the isolates from the Philippines. ${ }^{8}$ Recent reports, however, showed that new plasmid patterns of $N$ gonorrhoeae have appeared in various geographical localities. ${ }^{9-14}$ Auxotyping has provided useful information on the epidemiological characteristics of $N$ gonorrhoeae strains from various sources. ${ }^{15-17}$ The $24 \cdot 5 \mathrm{Mdal}$ plasmid was found previously only in wild type or proline requiring gonococcal isolates, but recent findings showed that the conjugative plasmid could be found in other auxotypes like arginine (ornithine) requiring isolates ${ }^{1011}$ and in a proline plus methionine (Pro ${ }^{-}+\mathrm{Met}^{-}$) requiring strain. ${ }^{18}$

In this study a new serogrouping technique ${ }^{19-23}$ was used in conjunction with auxotyping and plasmid

Address for reprints: Dr W L Albritton, Bacteriology Research Branch, STDLP Bldg 1 (Room 3254), Department of Health \& Human Services, Centers for Disease Control, Atlanta, Georgia 30333, USA

Accepted for publication 28 February 1983 analysis to characterise the gonococcal isolates from Korea.

\section{Materials and methods}

One hundred isolates of $N$ gonorrhoeae, including 30 strains of PPNG isolated from US military personnel in the Republic of Korea, were kindly provided for the study by the Walter Reed Army Institute of Research, Washington DC, USA.

The $\beta$-lactamase production of each gonococcal isolate was retested by using chromogenic cephalosporin (Glaxo Laboratories) ${ }^{24}$ and a starch paper technique. ${ }^{25}$ After reconfirming the identity of the gonococcal isolates by colonial morphology, oxidase test, and sugar utilisation patterns we stored all the cultures at $-20^{\circ} \mathrm{C}$ in defibrinated rabbit blood pending further laboratory investigation. Included in the study were a reference PPNG strain carrying 2.6 Mdal and 3.2 Mdal plasmids (CDC 82-057010); an Escherichia coli strain carrying a gonococcal $3 \cdot 2$ Mdal plasmid; gonococcal strains (CDC 65-082) carrying a $24 \cdot 5$ Mdal plasmid, $79 C^{\prime}$ carrying a $7 \cdot 8$ Mdal plasmid, and an African strain (LUNG 10) carrying 2.6 Mdal and 4.4 Mdal plasmids.

Plasmid deoxyribonucleic acid (DNA) from the cleared lysate was precipitated with ethanol and then subjected to agarose gel electrophoresis. ${ }^{26}$ The gel was stained in a solution of ethidium bromide in water $(1 \mu \mathrm{g} / \mathrm{ml})$ for 30 minutes. The plasmid DNA bands were visualised with a short wave ultraviolet 
light source (FOTO-UV* System, Fotodyne, New Berlin, Wisconsin, USA), and photographed with a Polaroid MP.4 land camera (Polaroid Corporation, Cambridge, Massachusetts, USA). Plasmids of known molecular weight were included as standards. Nutritional growth requirements of each gonococcal isolate were determined on gonococcal genetic medium. ${ }^{16} 17$

Serological grouping based on $\mathrm{W}$ antigens of gonococci was carried out using coagglutination methods. ${ }^{20-23}$

\section{Results}

Table I shows that a 4.4 Mdal plasmid was present in all the 30 PPNG strains tested. Of the 100 strains from Korea a conjugative $24 \cdot 5 \mathrm{Mdal}$ plasmid was present in 80, 29 of which were PPNG strains. The relation between plasmid content and auxotype showed that the 24.5 Mdal plasmid was present in three strains with auxotypes other than wild type and proline requiring; two of these strains were rare tyrosine requiring isolates, while the remaining strain was arginine requiring. The $7 \cdot 8 \mathrm{Mdal}$ plasmid, which is also rare, was present in four isolates in the study, one of which was a PPNG strain.

* Use of trade names is for identification only and does not imply endorsement by the Public Health Service or by the US Department of Health and Human Services.

TABLE I Relation between plasmid content and auxotype of Neisseria gonorrhoeae isolates from Korea

\begin{tabular}{lccccc}
\hline & \multicolumn{5}{c}{ No of isolates with following auxotype: } \\
\cline { 2 - 6 } (molasmid profile & Wild & Pro & Tyr & Arg & Total \\
\hline $2 \cdot 6$ & 9 & 10 & & & 19 \\
$2 \cdot 6+24 \cdot 5$ & 38 & 7 & 2 & 1 & 48 \\
$2 \cdot 6+7 \cdot 8+24 \cdot 5$ & $11^{*}$ & 3 & & & 3 \\
$2 \cdot 6+4 \cdot 4$ & $28^{*}$ & & & & $1^{*}$ \\
$2 \cdot 6+4 \cdot 4+24 \cdot 5$ & $1^{*}$ & & & & $1^{*}$ \\
$2 \cdot 6+4 \cdot 4+7 \cdot 8+24 \cdot 5$ & 77 & 20 & 2 & 1 & 100 \\
Total & & & & &
\end{tabular}

*PPNG strains.

Mdal = megadaltons.

TABLE II Relation between auxotype and serogroup of $P P N G$ and non-PPNG isolates from Korea

\begin{tabular}{lllr}
\hline \multicolumn{2}{l}{ No of isolates with: } & \\
\hline Auxotype & Serogroup WI & Serogroup WII & Total \\
\hline Wild Type & 2 & $45(30)^{*}$ & 77 \\
Pro- & & 20 & 20 \\
Tyr- & 2 & 2 \\
Arg- & & 1 & 1 \\
Total & 2 & 98 & 100 \\
\hline
\end{tabular}

*There were 30 PPNG strains, all of which were wild type and belonged to serogroup WII.

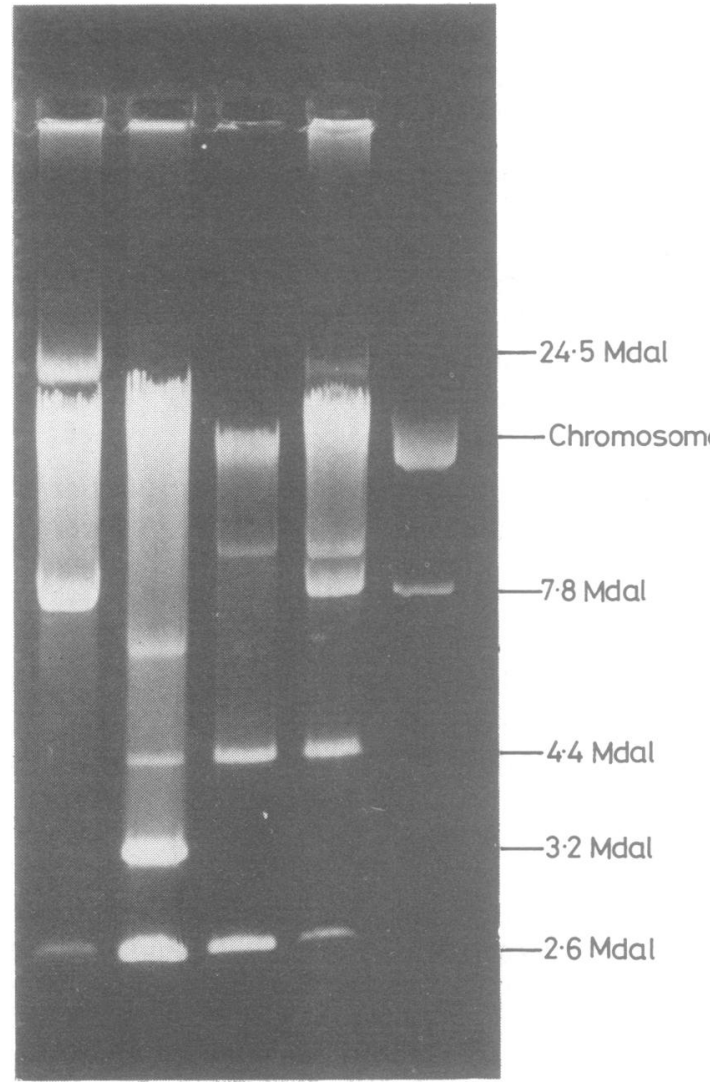

FIG 1 Agarose gel electrophoresis of crude lysates of isolates of Neisseria gonorrhoeae: column 1-Korean non-PPNG strain, CDC 82-057912; column 2-reference strain 82-057010; column 3-reference strain LUNG 10; column 4-a Korean PPNG strain, CDC 82-077028; and column 5-reference strain, CDC 79C'. (Mdal = megadaltons.)

Figs 1 and 2 show $0.7 \%$ agarose gels of electrophoresed crude lysates of representative strains.

The results of the serogroups of the $N$ gonorrhoeae strains in relation to their auxotypes are summarised in table II. Of the 100 strains, 98 belonged to serogroup WII. The only two strains that belonged to serogroup WI were non-PPNG, and their auxotype was the wild type.

\section{Discussion}

The findings in this study indicate new plasmid and auxotype patterns in strains from the Far East. It is noteworthy that about $80 \%$ of gonococcal isolates from Korea possessed the conjugative $24.5 \mathrm{Mdal}$ plasmid, whereas fewer isolates from the Philippines possessed this type of plasmid. Recent reports have 


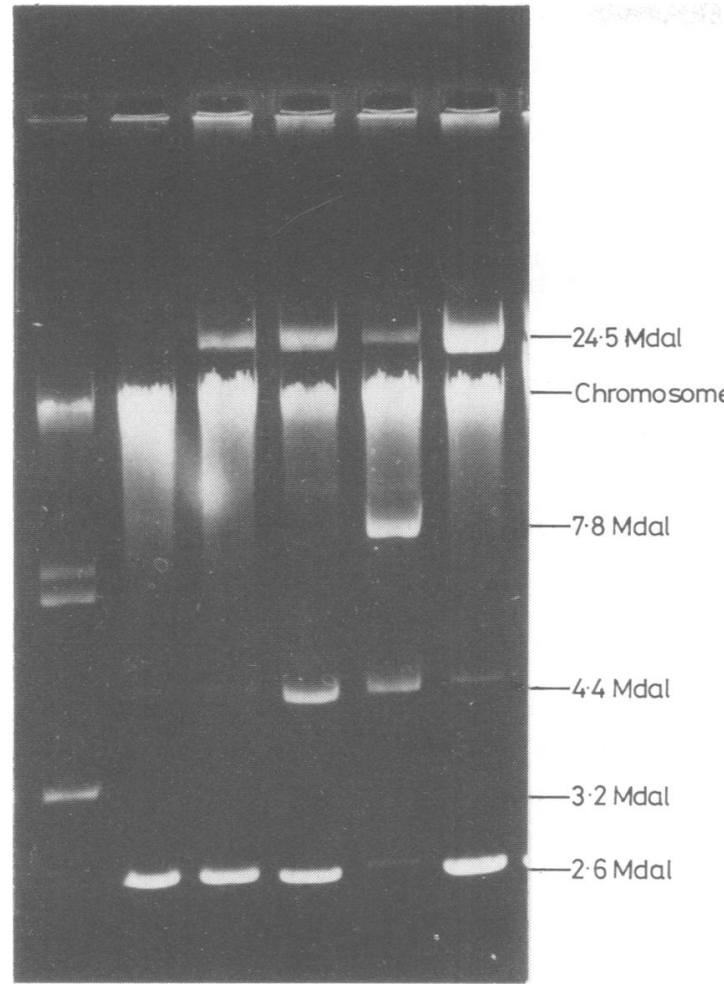

FIG 2 Agarose gel electrophoresis of crude lysates of gonococcal isolates: column 1-reference 3.2 Mdal plasmid in Escherichia coli; column 2-a Korean nonPPNG strain (CDC 82-057931); column 3-a Korean strain CDC 82-057934; column 4-reference strain, CDC 65-082; column 5-a Korean strain CDC 82-077028; and column 6-a Korean non-PPNG strain, CDC 82-057882. (Mdal = megadalton.)

suggested genetic exchange within the gonococcal population. ${ }^{10-141827}$ The $24 \cdot 5$ Mdal conjugative plasmid, which was previously present only in the wild type or proline requiring isolates, was reported to be present in one ornithine requiring strain from Canada, ${ }^{10}$ three arginine (ornithine) requiring strains from Holland, ${ }^{11}$ and one proline plus methionine requiring strain from Britain. ${ }^{18}$ In this study we found an additional three strains, two of which had an unusual tyrosine requiring auxotype with the one remaining strain having an arginine requiring auxotype.

It is interesting that four of the 100 strains from Korea possessed a newly described $7 \cdot 8$ Mdal plasmid. The fact that this $7 \cdot 8 \mathrm{Mdal}$ plasmid was present in both PPNG and non-PPNG strains suggests that the plasmid does not code for $\beta$-lactamase. In a previous study from our laboratory only three strains of $N$ gonorrhoeae were found to possess the novel 7.8 Mdal plasmid (Johnson et al, unpublished data). van Embden et al isolated a PPNG strain in Holland carrying a 7.5 Mdal cryptic plasmid which might be identical to our $7.8 \mathrm{Mdal}$ plasmid. ${ }^{27}$

The predominant auxotypes in this study were wild type (77) and proline requiring (20) (table II). All the 30 PPNG strains were the wild type and belonged to serogroup WII, which had a total of 98 strains. These findings are in accord with other reports which indicated that serogroup WII is predominant in the Far East, while serogroup WI is predominant in West Africa. ${ }^{14} 1922$

T O Odugbemi is a recipient of the Fogarty International Fellowship of the National Institutes of Health (fellowship No 1 FO5 TWO 3107-01).

The gonococcal monoclonal antibody reagents were kindly provided by Genetic Systems Corporation, Seattle, Washington, USA. The staphylococcal reagent containing protein A was provided by Pharmacia Diagnostics, Uppsala, Sweden.

\section{References}

1. Ashford WA, Golash RG, Hemming VG. Penicillinaseproducing Neisseria gonorrhoeae. Lancet 1976; ii:657-8.

2. Percival A, Corkill JE, Arya OP, et al. Penicillinase-producing gonococci in Liverpool. Lancet 1976; ii: 1379-82.

3. Phillips I. Beta-lactamase-producing penicillin-resistant gonococcus. Lancet 1976; ii: 656-57.

4. Elwell LP, Roberts M, Mayer LW, Falkow S. Plasmidmediated beta-lactamase production in Neisseria gonorrhoeae. Antimicrob Agents Chemother 1977;11:528-33.

5. Perine PL, Thornsberry C, Schalla, W, et al. Evidence for two distinct types of penicillinase-producing Neisseria gonorrhoeae. Lancet 1977; ii:993-5.

6. Roberts $M$, Falkow $S$. Conjugal transfer of $R$ plasmids in Neisseria gonorrhoeae. Nature 1977; 266:630-1.

7. Sox TE, Mohammed W, Blackman E, Biswas G, Sparling PF. Conjugative plasmids in Neisseria gonorrhoeae. J Bacteriol 1978; 134:278-86.

8. Roberts M, Piot P, Falkow S. The ecology of gonococcal plasmids. J Gen Microbiol 1979; 114:491-4.

9. Jephcott AE, Dickgiesser N, McClean AM. Penicillinaseproducing gonococci in Britain. Lancet 1981; ii:247-8.

10. Dillon JR, Pauze M. Appearance in Canada of Neisseria gonorrhoeae strains with a 3·2-megadalton penicillinaseproducing plasmid and a $24 \cdot 5$-megadalton transfer plasmid. Lancet $1981 ; \mathrm{ii}: 700$.

11. Ansink-Schipper MD, Woudstra R. Further spread of plasmids among different auxotypes of penicillinase-producing gonococci. Lancet $1982 ; \mathrm{i}: 445$.

12. Johnston NA, Kolator B. Emergence in Britain of betalactamase-producing gonococci with new plasmid combination. Lancet 1982; i: $445-6$.

13. Anderson B, Odugbemi T, Johnson S. Penicillinase-producing Neisseria gonorrhoeae strains from Nigeria with Far-Easterntype plasmid. Lancet $1982 ;$ i: 676 .

14. Odugbemi TO, Brown ST, Biddle J, et al. Plasmid, profile serogrouping, and auxotyping of Neisseria gonorrhoeae isolates from Africa. $\mathrm{Br} J$ Vener Dis 1983;59:41-3.

15. Knapp JS, Holmes KK. Disseminated gonococcal infections caused by Neisseria gonorrhoeae with unique nutritional requirements. J Infect Dis 1975; 132:204-8.

16. LaScolea LJ Jr, Young FE. Development of a defined minimal medium for the growth of Neisseria gonorrhoeae. Appl Microbiol 1974; 28: 70-6.

17. Short HB, Plowcow VB, Weiss JA, Young FE. Rapid method for auxotyping multiple strains of Neisseria gonorrhoeae. $J$ Clin Microbiol 1977;6:244-8. 
18. Jephcott AE, Egglestone SI, Copley C. Further evidence of dissemination of ability to produce penicillinase amongst gonococci. Lancet 1982; i: 1467-8.

19. Bygdeman S, Kallings I, Danielsson D. Serogrouping and auxotyping for epidemiological study of beta-lactamaseproducing Neisseria gonorrhoeae strains isolated in Sweden. Acta Derm Venereol (Stockh) 1981;6:329-34.

20. Sandström E, Danielsson D. Serology of Neisseria gonorrhoeae: classification by coagglutination. Acta Patho Microbiol Scand (B) 1980;88:27-38.

21. Sandström EG, Knapp JS, Buchanan TB. Serology of Neisseria gonorrhoeae: W-antigen serogrouping by coagglutination and protein I serology by enzyme-linked immunosorbent assay both detect protein I antigens. Infect Immun 1982;35:229-39.

22. Handsfield HH Sandström EG, Knapp JS, et al. Epidemiology of penicillinase-producing Neisseria gonorrhoeae infections: analysis by auxotyping and serogrouping. N Engl J Med 1982;306: 950-4.
23. Tam MR, Buchanan TM, Sandström EG, et al. Serological classification of Neisseria gonorrhoeae with monoclonal antibodies. J Bacteriol 1982; 36: 1042-53.

24. O'Callaghan $\mathrm{CH}$, Morris A, Kirby SM, Shingler AH. Novel method for detection of beta-lactamase by using cephalosporin substrate. Antimicrob Agents Chemother 1972;1:283-8.

25. Odugbemi TO, Hafiz S, McEntegart MG. Penicillinaseproducing Neisseria gonorrhoeae: detection by starch-paper technique. Br Med J 1977; ii: 500.

26. Meyers JA, Sanchez D, Elwell LP, Falkow S. Simple agarose gel electrophoretic method for identification and characterization of plasmid deoxyribonucleic acid. J Bacteriol 1976;127: 1529-37.

27. van Embden JDA, van Klingeren B, Dessens-Kroom M, van Wijgaarden $\mathrm{J}$. Penicillinase-producing Neisseria gonorrhoeae in the Netherlands: Epidemiology and genetic and molecular characterization of their plasmids. Antimicrob Agents Chemother 1980; 18: 789-97. 